\title{
Specjalne strefy ekonomiczne w przestrzeni gospodarczej województwa dolnośląskiego
}

Specjalna strefa ekonomiczna (SSE) jest pojęciem niejednoznacznym. W ujęciu prawnym jest to wyodrębniona administracyjnie część terytorium państwa, przeznaczona do prowadzenia działalności gospodarczej na korzystniejszych warunkach niż uwarunkowania wynikające z przepisów regulujących krajową działalność gospodarczą. W ujęciu ekonomicznym jest ona enklawą gospodarczą, stanowiącą instrument polityki gospodarczej, szczególnie strukturalnej i lokalizacyjnej, służący rozwojowi całego kraju oraz wspierający rozwój określonych jego regionów (Bazydło, Smętkowski 2000). W tym celu przedsiębiorcom realizującym swoje przedsięwzięcia inwestycyjne w specjalnych strefach ekonomicznych oferowany jest pakiet subsydiowanych usług w postaci pomocy publicznej państwa (Liberska 1999).

Podstawowym celem tworzenia specjalnych stref ekonomicznych jest przyciagnięcie kapitału, szczególnie zagranicznego, dla aktywizacji gospodarczej wybranych obszarów. Jest to możliwe przede wszystkim ze względu na rozwiązania instytucjonalne obejmujące ulgi i zwolnienia podatkowe, stymulujące zagospodarowanie wybranych regionów kraju, a zwłaszcza tworzenie nowych miejsc pracy na lokalnych rynkach, na których występują nadwyżki siły roboczej.

Do głównych przyczyn powoływania specjalnych stref ekonomicznych możemy zaliczyć:

- aktywizację gospodarczą regionów;

- restrukturyzację starych okręgów przemysłowych;

- zagospodarowanie majątku i infrastruktury po likwidowanych przedsiębiorstwach;

- tworzenie nowych miejsc pracy, zwłaszcza w obszarach dotkniętych i zagrożonych wysokim bezrobociem;

- rozwój i zastosowanie w gospodarce nowych rozwiązań technicznych i technologicznych;

- poprawę konkurencyjności produktów i usług.

Obecnie w Polsce funkcjonuje 14 specjalnych stref ekonomicznych, występujących w rozproszeniu na terenie całego kraju, w tym trzy na obszarze województwa dolnośląskiego: kamiennogórska, legnicka i wałbrzyska (ryc. 1). Wymienione strefy powołano na podstawie rozporządzeń w 1997 r. Przyczyną powstania SSE „Małej Przedsiębiorczości” w Kamiennej Górze (Rozporzqdzenie... 1997) jest obniżenie wysokiej stopy bezrobocia strukturalnego. Celem legnickiej SSE (Rozporzqdzenie... 1997) jest dywersyfikacja struktury gospodarczej 
regionu z uwagi na monokulturę przemysłu, związanego z eksploatacją i przetwórstwem złóż miedzi, oraz zagospodarowanie znacznych powierzchni produkcyjnych i urządzeń infrastruktury technicznej. Celem wałbrzyskiej SSE „Invest Park” (Rozporzqdzenie... 1997) jest restrukturyzacja przemysłu wydobywczego węgla kamiennego i związanego z nim kompleksu przemysłu ciężkiego zlikwidowanego zagłębia dolnośląskiego.

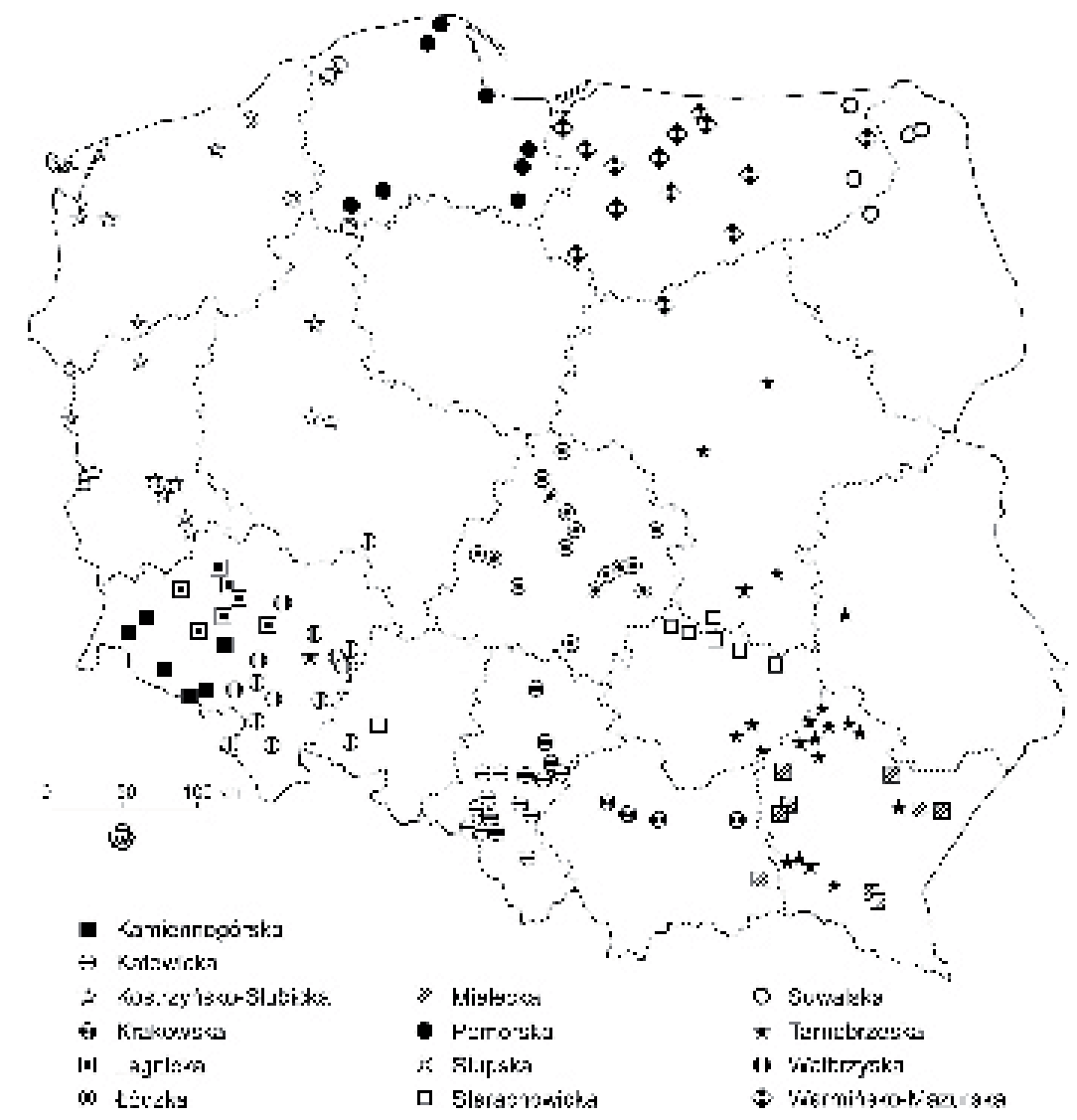

Ryc. 1. Rozmieszczenie specjalnych stref ekonomicznych w Polsce.

Stan na 31 grudnia 2005 r.

Źródło: Opracowanie własne

Zgodnie z ustaleniami przeprowadzonymi z Komisją Europejską liczba specjalnych stref ekonomicznych w Polsce już nie zwiększy się. W wyniku negocjacji akcesyjnych Polski do UE łączny obszar specjalnych stref ekonomicznych został określony według stanu na dzień 31 grudnia 2000 r. w wielkości 6325 ha. Od 30 maja 2004 r. dopuszczono możliwość zwiększenia powierzchni stref do 8000 ha, ale wyłącznie pod duże inwestycje, tj. pod inwestycje o nakładach nie mniejszych niż $40 \mathrm{mln}$ euro lub zatrudnieniu 500 osób.

Na koniec 2005 r. łączny obszar specjalnych stref ekonomicznych wynosił już 7558 ha, co oznaczało wykorzystanie potencjalnie dostępnego terenu prawie w całości (95\%). W celu rozwiązania problemu dostępności gruntów w strefach ekonomicznych rząd po raz kolejny 
znowelizował przepisy o strefach, które zakładają zwiększenie obszaru stref w Polsce o kolejne 4 tys. ha. Oznacza to, że łączny obszar wszystkich specjalnych stref ekonomicznych może wynieść 12 tys. ha. Powyższe uregulowania zaczęły obowiązywać 8 września $2006 \mathrm{r}$. Tak znaczne powiększenie obszaru stref pozwoli przyciągnąć nowych inwestorów bez obaw o sprzeciw Komisji Europejskiej, która może mieć zastrzeżenia wobec wysokości pomocy publicznej udzielanej w strefach, natomiast nie narzuca limitu obszarowego („Wiadomości Gospodarcze" 2006).

Najważniejszym atutem inwestowania na obszarze specjalnych stref ekonomicznych są ulgi podatkowe, które będą obowiązywać najdalej do 2017 r. Inwestorzy prowadzący działalność w strefach w 2005 r. korzystali ze zwolnień od podatku dochodowego do 50\%, a w przypadku małych i średnich przedsiębiorstw nawet do $65 \%$ kwoty kosztów kwalifikowanych, którymi są koszty inwestycji lub dwuletnie koszty pracy. Wyjątek stanowiła krakowska SSE, gdzie można było otrzymać zwolnienie do 40\% wartości inwestycji. Zwolnienie podatkowe z tytułu prowadzenia działalności w specjalnej strefie ekonomicznej można było otrzymać ze względu na wielkość inwestycji albo ze względu na tworzenie nowych miejsc pracy. Oprócz zwolnienia podatkowego przedsiębiorca mógł także skorzystać z innych przywilejów, np. otrzymać po konkurencyjnej cenie działkę w pełni przygotowaną pod inwestycję lub darmową pomoc przy załatwianiu formalności związanych z inwestycją oraz zwolnienie od podatku od nieruchomości („Wiadomości Gospodarcze” 2006) ${ }^{1}$.

Po 2017 r. specjalne strefy ekonomiczne utraca przywileje podatkowe i przekształcą się w parki technologiczne, inkubatory lub firmy świadczące usługi dla inwestorów. Pomoc dla inwestorów nie będzie określona przez ustawę o specjalnych strefach ekonomicznych, ale przez przepisy zawarte $\mathrm{w}$ ustawie o finansowym wsparciu inwestycji oraz w oparciu o instrumenty finansowe obowiązujące przy realizacji projektów inwestycyjnych w ramach Sektorowego Programu Operacyjnego Wzrost Konkurencyjności Przedsiębiorstw (Informacja o SSE 2006).

Województwo dolnośląskie charakteryzuje się bardzo wysoką podażą obszarów wchodzących w skład specjalnych stref ekonomicznych (ryc. 2). Udział omawianych enklaw gospodarczych regionu w łącznej powierzchni specjalnych stref ekonomicznych w kraju na koniec 2005 r. wynosił $18,6 \%$. W rezultacie na 29 powiatów województwa podstrefy specjalnych stref ekonomicznych znajdowały się aż w 20. Wobec powyższego województwo dolnośląskie należy do regionów o najwyższym stopniu koncentracji podstref w Polsce. Warto podkreślić, iż na obszarze województwa funkcjonuje dodatkowo podstrefa będąca częścią tarnobrzeskiej SSE, zlokalizowana w Biskupicach Podgórnych na obszarze gminy Kobierzyce w powiecie wrocławskim. Powstała ona w związku z ulokowaniem w pobliżu Wrocławia jednej z największych bezpośrednich inwestycji zagranicznych w Polsce, jaką jest wytwórnia ekranów ciekłokrystalicznych międzynarodowego koncernu LG Philips.

${ }^{1}$ Od 1 stycznia 2007 r. w Polsce obowiązują nowe zasady pomocy regionalnej na obszarach SSE na lata 2007-2013. Zgodnie z nimi, maksymalna wielkość regionalnej pomocy publicznej w SSE wynosi:

$50 \%$ - na obszarach należących do województw: lubelskiego, podkarpackiego, warmińsko-mazurskiego, podlaskiego, świętokrzyskiego, opolskiego, małopolskiego, lubuskiego, łódzkiego, kujawsko-pomorskiego,

$40 \%$ - na obszarach należących do województw: pomorskiego, zachodniopomorskiego, dolnośląskiego, wielkopolskiego, śląskiego, a w okresie od 1 stycznia 2007 r. do 31 grudnia 2010 r. na obszarze należącym do województwa mazowieckiego, z wyłączeniem miasta stołecznego Warszawy;

$30 \%$ - na obszarze należącym do miasta stołecznego Warszawy oraz w okresie od 1 stycznia 2011 r. do 31 grudnia 2013 r. - na obszarze należącym do województwa mazowieckiego. Podwyższanie skali pomocy ma miejsce w stosunku do przedsiębiorstw z sektora MSP (szerzej: Rozporządzenie RM zmieniające rozporządzenie w sprawie udzielenia wsparcia nowej inwestycji z Funduszu Strefowego, Dz. U. z 2007, nr 45 poz. 289 oraz www.paiz.gov.pl). 


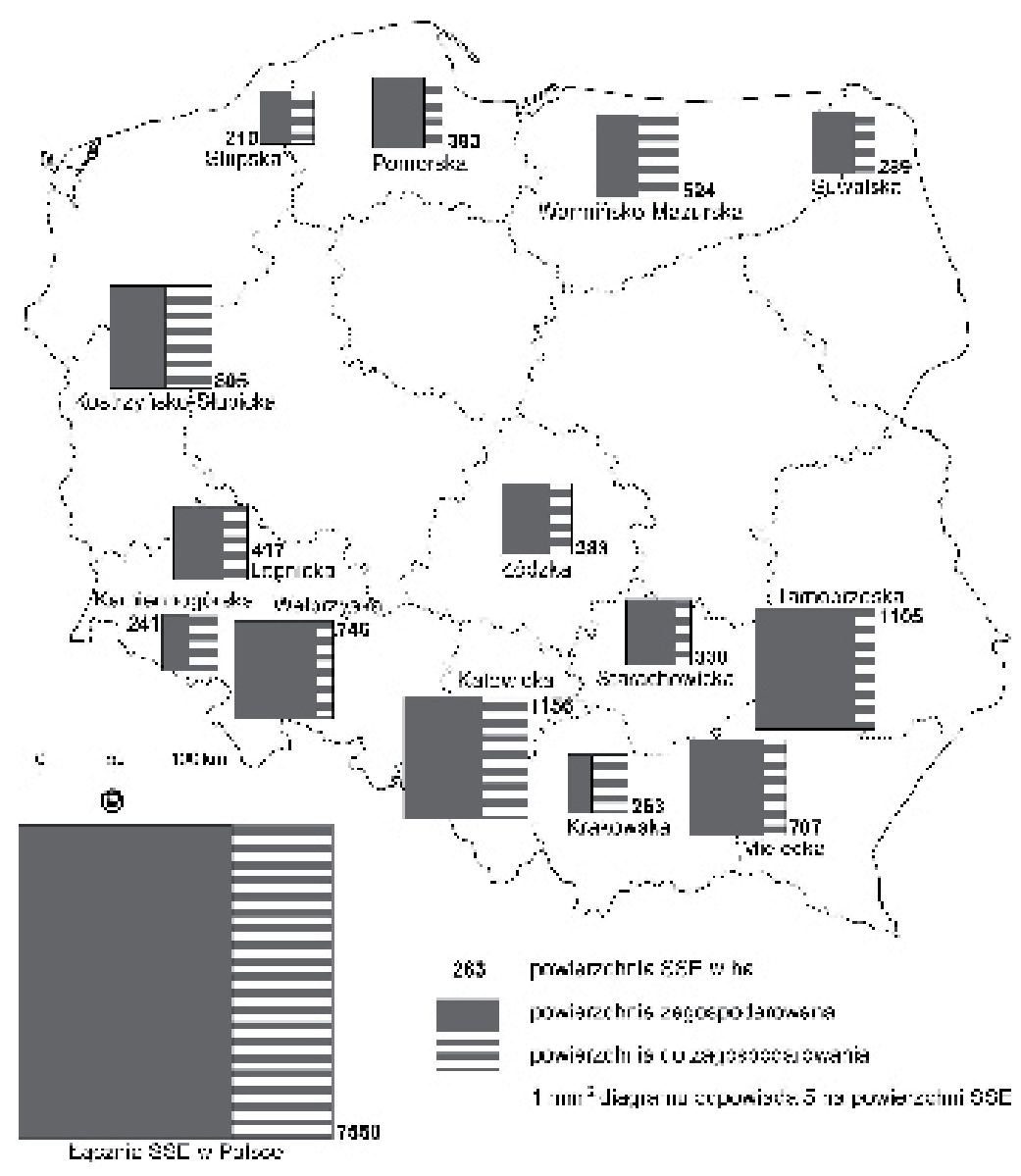

Ryc. 2. Powierzchnia i stopień zagospodarowania specjalnych stref ekonomicznych.

Stan na 31 grudnia $2005 \mathrm{r}$.

Źródło: Opracowanie własne na podstawie Informacje o specjalnych... 2006

Dolnośląskie strefy charakteryzują się wysokim stopniem koncentracji w obrębie województwa (wyjątek stanowią 2 podstrefy wałbrzyskiej SSE w Krotoszynie i Nysie) - podobnie jak łódzka, katowicka czy warmińsko-mazurska SSE, a w przeciwieństwie do kostrzyńsko-słubickiej, której podstrefy zlokalizowane są na obszarze aż trzech województw: lubuskiego, wielkopolskiego i zachodniopomorskiego.

Stopień zagospodarowania specjalnych stref ekonomicznych w województwie dolnośląskim jest znacznie zróżnicowany, zarówno w układzie poszczególnych stref, jak i ich części składowych - podstref.

Najbardziej zagospodarowaną strefą w regionie jest wałbrzyska SSE. Na koniec 2005 r. $84 \%$ jej powierzchni było już zagospodarowane, przy przeciętnej krajowej wynoszącej 70\%. Stosunkowo wysokim stopniem zagospodarowania cechuje się także legnicka SSE z wynikiem ponad $67 \%$. Najmniejszy odsetek zagospodarowanej powierzchni ma kamiennogórska SSE $(49 \%)$. 
Wartość nakładów inwestycyjnych na obszarze specjalnych stref ekonomicznych w Polsce do końca 2005 r. wyniosła 25,7 mld zł. Udział kapitału ulokowanego na obszarze stref w województwie dolnośląskim stanowił ponad 30\% tej kwoty. Największe nakłady miały miejsce w wałbrzyskiej SSE, która jednocześnie uplasowała się na drugim miejscu w Polsce, po katowickiej SSE, z wartością blisko 4,6 mld zł. Trzecią lokatę w kraju pod względem dokonanych nakładów inwestycyjnych, z wartością 2,8 mld zł, zajęła legnicka SSE. Najmniejsze nakłady inwestycyjne miały miejsce w kamiennogórskiej SSE, gdzie wartość inwestycji przekroczyła niespełna 0,6 mld zł (ryc. 3).

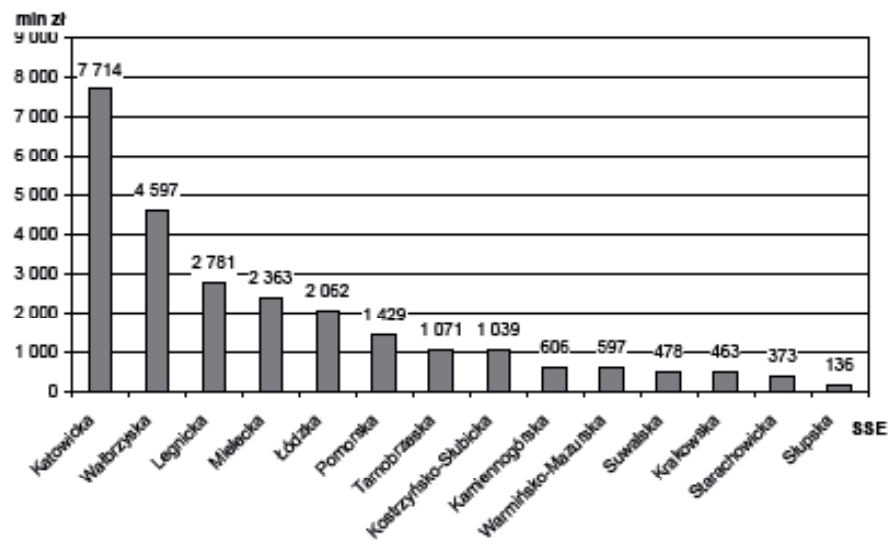

Ryc. 3. Nakłady inwestycyjne w specjalnych strefach ekonomicznych. Stan na 31 grudnia $2005 \mathrm{r}$.

Źródło: Informacje o specjalnych... 2006

Na szczególną uwagę zasługuje struktura branżowa nakładów inwestycyjnych w specjalnych strefach ekonomicznych w Polsce. Zdecydowanie największy udział miała branża motoryzacyjna $-37 \%$, następnie papiernicza $-12 \%$, tworzyw sztucznych $-10 \%$, produkcja wyrobów z surowców niemetalicznych - 8\% i urządzeń elektrycznych - 7\%. Udział pozostałych branż nie przekraczał 6\% (ryc. 4).

Ta stosunkowo zdywersyfikowana struktura branżowa nakładów inwestycyjnych w strefach może świadczyć o stymulującym oddziaływaniu stref na regionalne gospodarki i stwarzać podstawy do oczekiwanych przekształceń strukturalnych w obszarach, w których je powołano.

Branża motoryzacyjna zdominowała także inwestycje dokonane w strefach dolnośląskich. We wszystkich trzech funkcjonujących na Dolnym Śląsku jej udział wyniósł 50\% i więcej, jak np. w wałbrzyskiej SSE. Za pozytywne należy uznać również pojawiające się przedsięwzięcia inwestycyjne związane z produkcją tworzyw sztucznych czy urządzeń elektrycznych.

Dokonane inwestycje w specjalnych strefach na obszarze województwa przyczyniają się do pozytywnych przekształceń strukturalnych i poprawy systemu gospodarczego regionu. Poprzez specjalne strefy ekonomiczne Dolny Śląsk staje się znaczącym centrum przemysłu motoryzacyjnego (w legnickiej SSE: produkcja silników Volkswagena i części samochodowych w fabryce Sitech, w wałbrzyskiej SSE: silników Toyoty w Wałbrzychu i w JelczuLaskowicach) oraz produkcji sprzętu AGD za sprawą kompleksowej inwestycji Elektroluxa w wałbrzyskiej SSE, tj. zmywarek w Żarowie, pralek w Oławie i lodówek w Świdnicy. 


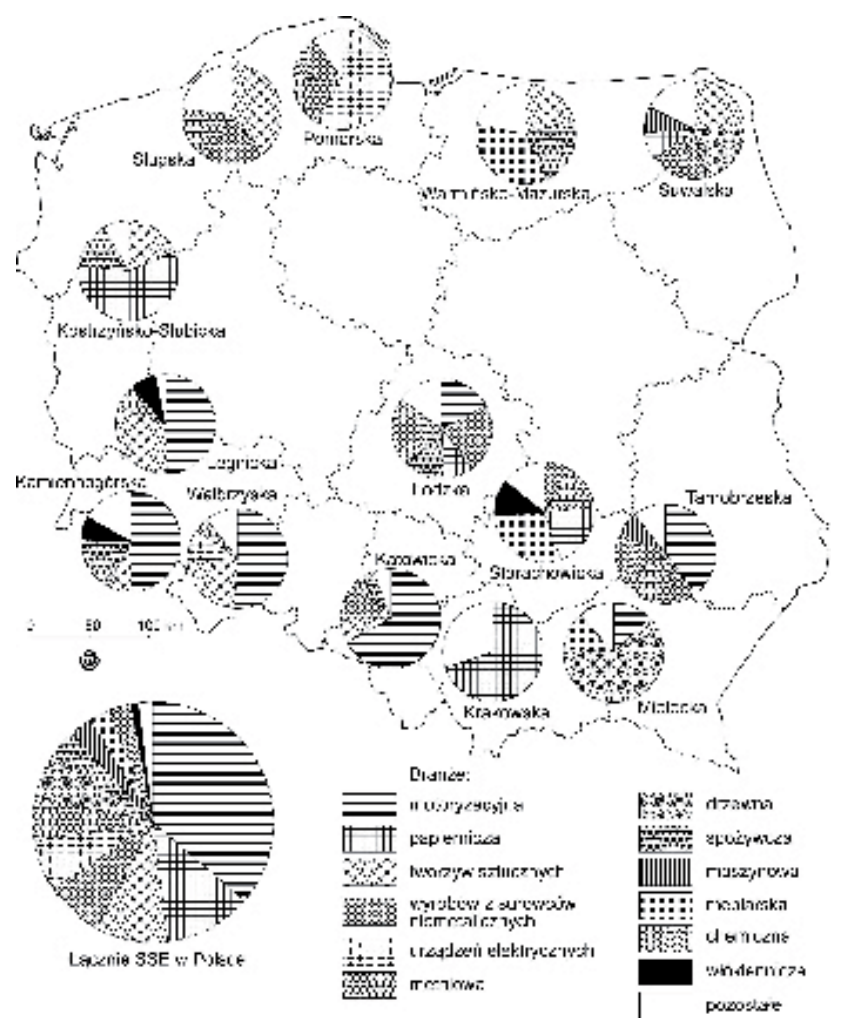

Ryc. 4. Struktura branżowa nakładów inwestycyjnych w specjalnych strefach ekonomicznych. Stan na 31 grudnia 2005 r.

Źródło: Opracowanie własne na podstawie Informacje o specjalnych... 2006

Realizowane przedsięwzięcia inwestycyjne w specjalnych strefach ekonomicznych mogą również pozytywnie oddziaływać na rynek pracy. Nabiera to szczególnego znaczenia w obszarach dotkniętych wysokim bezrobociem, za sprawą dokonujących się na ich obszarze przekształceń strukturalnych, lub niskim poziomem przedsiębiorczości. Między innymi w takich obszarach pierwotnie powoływano analizowane enklawy gospodarcze, np. kamiennogórską, częstochowską, tczewską ${ }^{2}$ („Prawo i Gospodarka” 2001), warmińsko-mazurską, suwalską czy słupską SSE.

Pomimo iż strefy przyniosły mniejsze efekty ekonomiczne od spodziewanych, zarówno pod względem wielkości inwestycji, jak i kreowania nowych miejsc pracy (Raport o polityce regionalnej 2004), to analizując zatrudnienie w strefach można jednak stwierdzić, że faktyczna liczba miejsc pracy utworzonych do końca marca 2005 r. przekracza deklaracje ujęte w zezwoleniach. Od początku działalności specjalnych stref ekonomicznych powstało 82 tys. miejsc pracy. Łącznie w przedsiębiorstwach zlokalizowanych w strefach pracowało

${ }^{2}$ W latach 1995-1997 rząd utworzył 17 specjalnych stref ekonomicznych. W dwóch strefach: częstochowskiej i mazowieckiej nie ulokował się żaden inwestor i w $2001 \mathrm{r}$. zostały one zlikwidowane. W tym samym roku połączono strefy: tczewską i żarnowiecką, tworząc pomorską SSE. „Zlikwidowane” w ten sposób obszary mogły zostać zagospodarowane przez pozostałe strefy. 
pod koniec 2005 r. 112 tys. pracowników. Najwięcej w katowickiej, wałbrzyskiej i mieleckiej SSE (ryc. 5).

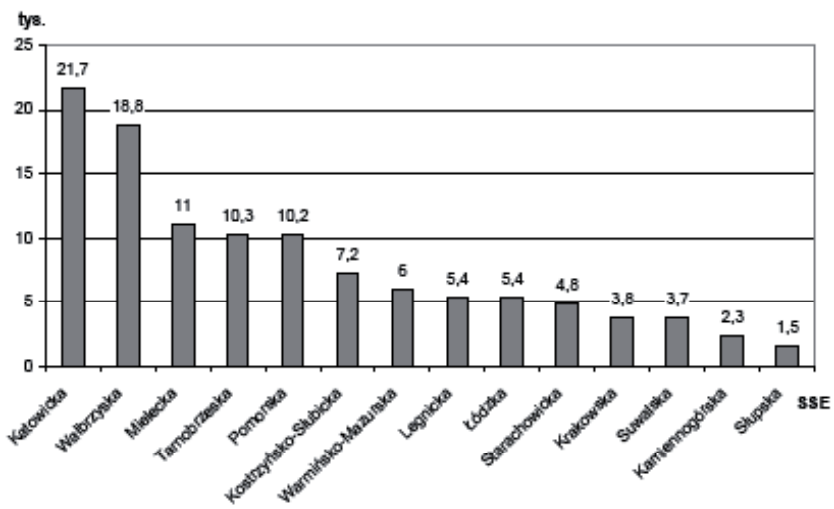

Ryc. 5. Liczba miejsc pracy w specjalnych strefach ekonomicznych. Stan na 31 grudnia $2005 \mathrm{r}$.

Źródło: Informacje o specjalnych ... 2006

W województwie dolnośląskim w firmach funkcjonujących w specjalnych strefach ekonomicznych pracowało łącznie 26,5 tys. osób, co stanowiło blisko $24 \%$ wszystkich pracujących w przedsiębiorstwach zlokalizowanych na obszarze stref w kraju. W tym wypadku również wałbrzyska SSE (podobnie jak w zakresie wartości nakładów inwestycyjnych) uplasowała się na 2 pozycji w kraju. Dalsze miejsce zajęła legnicka, zaś przedostatnie kamiennogórska SSE.

Wysoka pozycja w 2005 r. legnickiej SSE wśród stref w Polsce w zakresie wartości (trzecia), a znacznie niższa w odniesieniu do stworzonych miejsc pracy (dopiero ósma) świadczyć może, iż przedsięwzięcia inwestycyjne na jej obszarze są związane z nowoczesnymi technologiami pozwalającymi zwiększać wydajność bez konieczności zatrudniania dodatkowych pracowników.

Efektywność zagospodarowania specjalnych stref ekonomicznych mierzona średnią wartością nakładów inwestycyjnych oraz średnią liczbą utworzonych miejsc pracy na 1 ha zagospodarowanej powierzchni wykazuje znaczne przestrzenne zróżnicowanie (ryc. 6). Najbardziej efektywne w Polsce na koniec 2005 r. okazały się nakłady inwestycyjne w legnickiej SSE, które osiągnęły wartość $15,9 \mathrm{mln}$ zł na 1 ha zagospodarowanej powierzchni. Stosunkowo wysoką wartość osiąnęła także wałbrzyska SSE z wynikiem jednak o połowę mniejszym od legnickiej, lecz przy średniej krajowej wynoszącej 5,6 mln zł na 1 ha zagospodarowanej powierzchni.

Wysoką efektywność zagospodarowania powyższe dwie strefy z Dolnego Śląska uzyskały także w zakresie drugiego wskaźnika, odnoszącego się do zatrudnienia. W tym wypadku zarówno legnicka, jak i wałbrzyska SSE osiągnęły wysokie wartości w kraju, odpowiednio 31 i 32 miejsca pracy na 1 ha zagospodarowanej powierzchni, ustępując jedynie pomorskiej SSE (40). Dla porównania przeciętna wartość tego wskaźnika w kraju wyniosła 24 miejsca pracy na 1 ha zagospodarowanej powierzchni. Najniższa efektywność w zagospodarowaniu strefy w regionie cechuje kamiennogórską SSE.

Badanie oddziaływania specjalnych stref ekonomicznych na gospodarkę w układach regionalnych i lokalnych jest znacznie utrudnione, z uwagi na fakt, iż nie wszystkie stre- 
fy można „domknąć” w granicach województw. Określenie znaczenia i wpływu omawianych enklaw gospodarczych na rozwój regionalnej i lokalnej gospodarki wymaga badania procesów inwestycyjnych w strefach w układzie ich podstref. Niestety uzyskanie pełnych i wiarygodnych informacji o wartości zainwestowanego kapitału oraz wielkości zatrudnienia w poszczególnych podstrefach jest czasami wręcz niemożliwe.

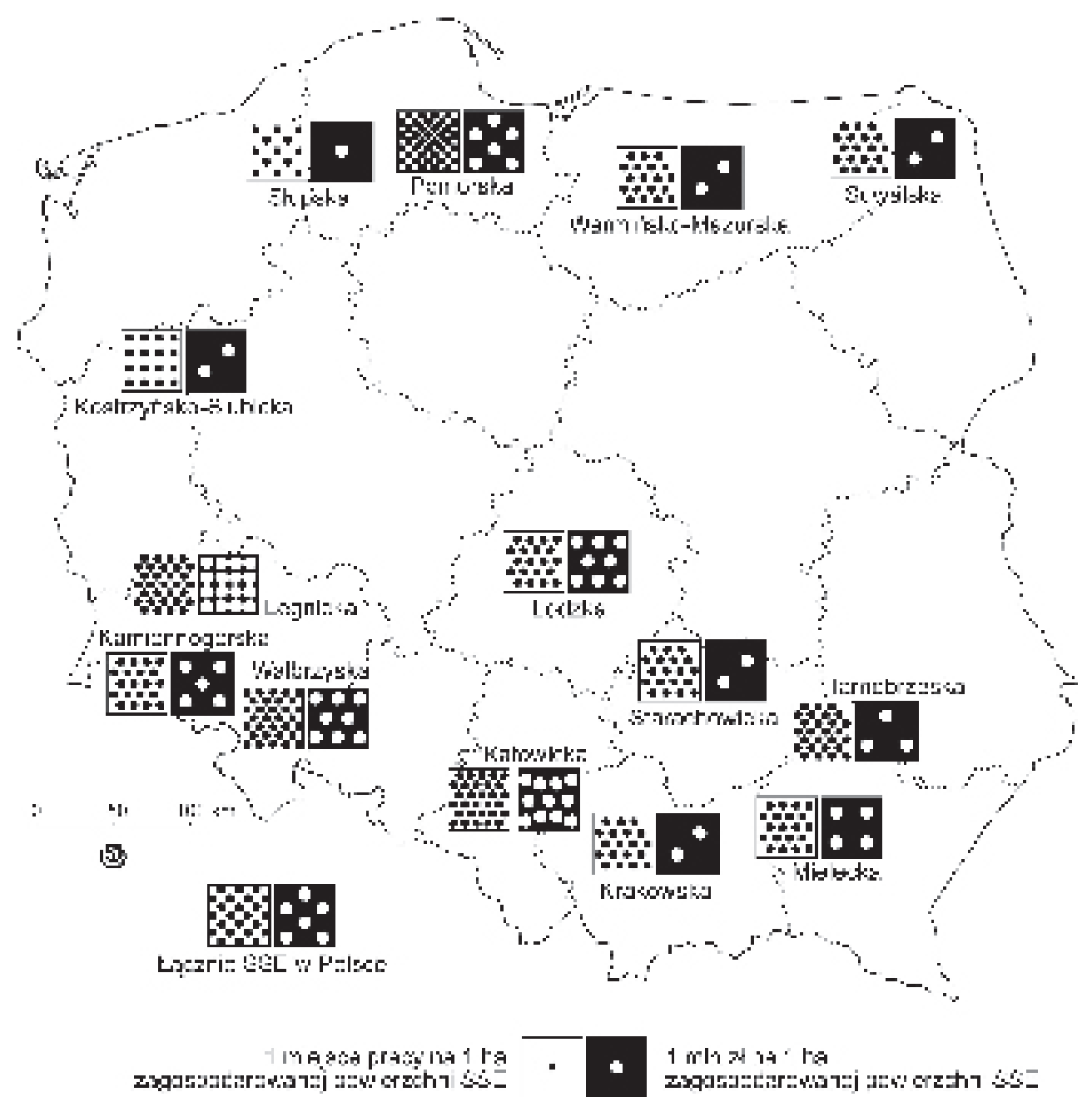

Ryc. 6. Efektywność zagospodarowania specjalnych stref ekonomicznych.

Stan na 31 grudnia $2005 \mathrm{r}$.

Źródło: Opracowanie własne na podstawie Informacje o specjalnych... 2006

Inwestycje realizowane w specjalnych strefach ekonomicznych mają wpływ na proces restytucji majątku trwałego w gospodarkach regionów, w których są one zlokalizowane. Widoczne jest to także na przykładzie województwa dolnośląskiego. Od momentu rozpoczęcia procesu inwestycyjnego w strefach dolnośląskich, tj. od 1997 r. do 2005 r., wartość do- 
konanych nakładów inwestycyjnych na obszarze stref stanowiła ponad 1/3 łącznej wartości poniesionych nakładów inwestycyjnych w całej gospodarce regionu.

Analiza relacji nakładów inwestycyjnych w specjalnych strefach ekonomicznych w odniesieniu do wartości brutto środków trwałych wybranych województw (w stosunku do tych w 2005 r., w których granicach administracyjnych można było „domknąć” większość podstref tworzących daną strefę ekonomiczną) pozwala zauważyć istotne znaczenie stref w gospodarkach tych regionów. Relacja ta w wypadku przemysłu województwa dolnośląskiego była najwyższa spośród analizowanych regionów i wynosiła blisko 18\%. Należy podkreślić, iż była ona ponad dwukrotnie wyższa niż w przemyśle województwa śląskiego (ryc. 7A).

Warto również zwrócić uwagę na doniosłe znaczenie dokonanych inwestycji w strefach w regionach o stosunkowo niskim wyposażeniu w środki trwałe. Kilka zrealizowanych projektów może odegrać znaczącą rolę w oddziaływaniu na komponent regionalnej gospodarki, jakim jest majątek trwały. Przykładem takiego oddziaływania jest województwo warmińsko-mazurskie, w którym charakteryzowana relacja w przemyśle wyniosła ponad $6 \%$ i była o $2 \%$ niższa niż w województwie śląskim.

Inwestycje w specjalnych strefach ekonomicznych oddziałują nie tylko na majątek regionalnej gospodarki, ale także na jej rynek pracy. W tym wypadku oddziaływanie stref może być nieco słabsze (w sensie tworzenia znacznej liczby nowych miejsc pracy) z uwagi na fakt, iż współczesne przedsięwzięcia inwestycyjne zaawansowane technologicznie nie wymagają dużej liczby pracowników. Stąd relacje pracujących w przedsiębiorstwach zlokalizowanych na obszarze stref w stosunku do całkowitej liczby pracujących w regionie są niższe od relacji związanych z majątkiem trwałym. W tym wypadku w województwie dolnośląskim relacja pracujących w podmiotach na obszarze specjalnych stref ekonomicznych w odniesieniu do ogółu pracujących w przemyśle regionu wyniosła ponad 4\% i była dwukrotnie wyższa niż w województwie śląskim czy warmińsko-mazurskim (ryc. 7B).

Przedsięwzięcia inwestycyjne w strefach ekonomicznych mają szczególne znaczenie dla gospodarek lokalnych. Mogą bowiem odegrać stymulującą rolę w rozwoju wszystkich dziedzin życia gospodarczego danego powiatu. W tym wypadku posłużono się przykładem legnickiej SSE, głównie z powodu możliwości uzyskania danych w układzie podstref(ryc. 8).

Podobnie jak w przypadku specjalnych stref ekonomicznych w Polsce, również w wypadku analizowanej strefy obserwujemy znaczne zróżnicowanie jej podstref pod względem inwestycji. Największych inwestycji dokonano w dwóch podstrefach w Legnicy i Polkowicach. Stosunkowo niskim poziomem zagospodarowania charakteryzują się podstrefy w Złotoryi, Krzywej i Gromadce. Do końca 2005 r. nie zrealizowano jeszcze żadnej inwestycji w podstrefach w Lubinie oraz Środzie Śląskiej, ale już wydane są na nie zezwolenia.

W przypadku oddziaływania na majątek trwały w wyżej wymienionych jednostkach terytorialnych relacja dokonanych nakładów inwestycyjnych w strefach $\mathrm{w}$ odniesieniu do wartości brutto środków trwałych w przemyśle na koniec 2005 r. wyniosła blisko 50\% w Legnicy i ponad 35\% w powiecie polkowickim (ryc. 8B i C). Istotną rolę powyższe podstrefy odgrywają także w kreowaniu rynku pracy na obszarach wymienionych powiatów. Pracujący w strefach stanowili w analizowanym roku blisko 19\% ogółu pracujących w przemyśle powiatu polkowickiego oraz $21 \% \mathrm{w}$ przemyśle Legnicy (ryc. $8 \mathrm{D}$ i E). Istotną rolę legnicka SSE odgrywa więc w gospodarce powiatu polkowickiego i w Legnicy.

Oddziaływanie podstrefy nie ogranicza się jedynie do powiatu, na którym jest ona zlokalizowana, tym bardziej iż z szacunków Ministerstwa Gospodarki i Pracy wynika, że 100 nowych miejsc pracy utworzonych w strefie generuje, w zależności od branży, od 50 do 100 nowych miejsc pracy w jej otoczeniu. Wzrasta bowiem zatrudnienie $\mathrm{w}$ firmach bu- 
dowlanych, w firmach kooperujących z zakładami funkcjonującymi w strefie oraz rozwijają się usługi transportowe, edukacyjne itp. Ulega również poprawie infrastruktura techniczna i społeczna w obszarach zlokalizowanych w pobliżu stref oraz wzrasta zapotrzebowanie na obsługę finansową firm (,Wiadomości Gospodarcze” 2006).

A

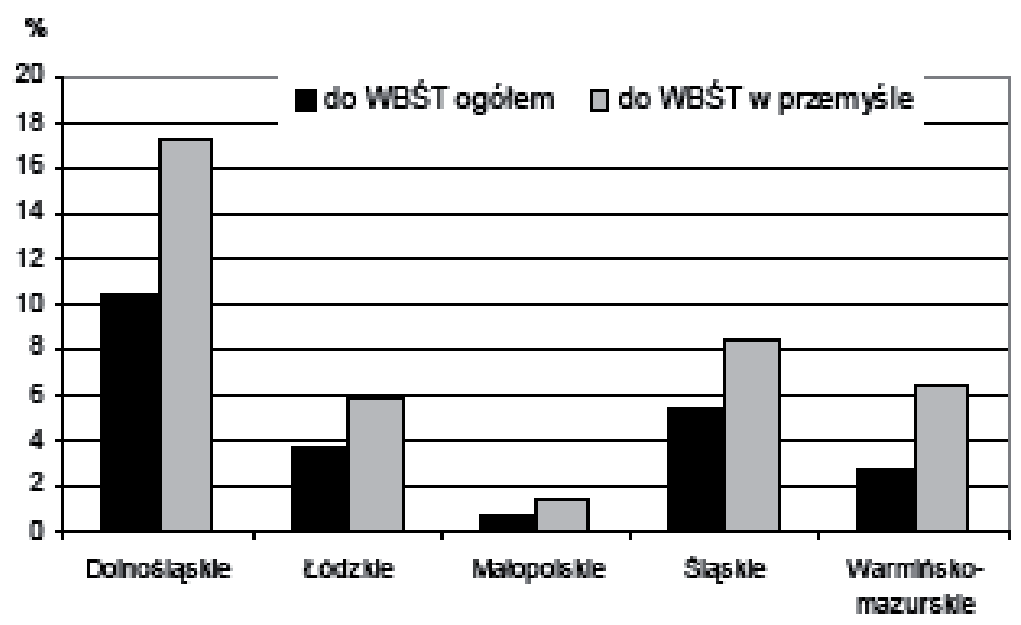

B

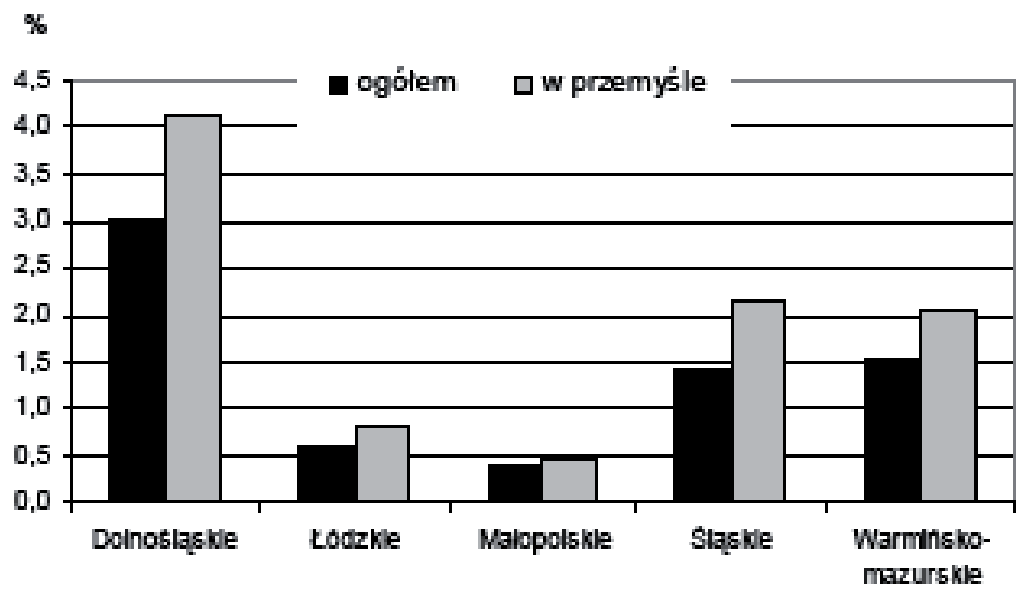

Ryc. 7.

A - Relacja nakładów inwestycyjnych w specjalnych strefach ekonomicznych do wartości brutto środków trwałych w wybranych województwach w 2005 r.

B - Udział pracujących w specjalnych strefach ekonomicznych w liczbie pracujących ogółem w wybranych województwach w $2005 \mathrm{r}$.

Źródło: Opracowanie własne na podstawie Informacje o specjalnych... 2006 i danych GUS. 

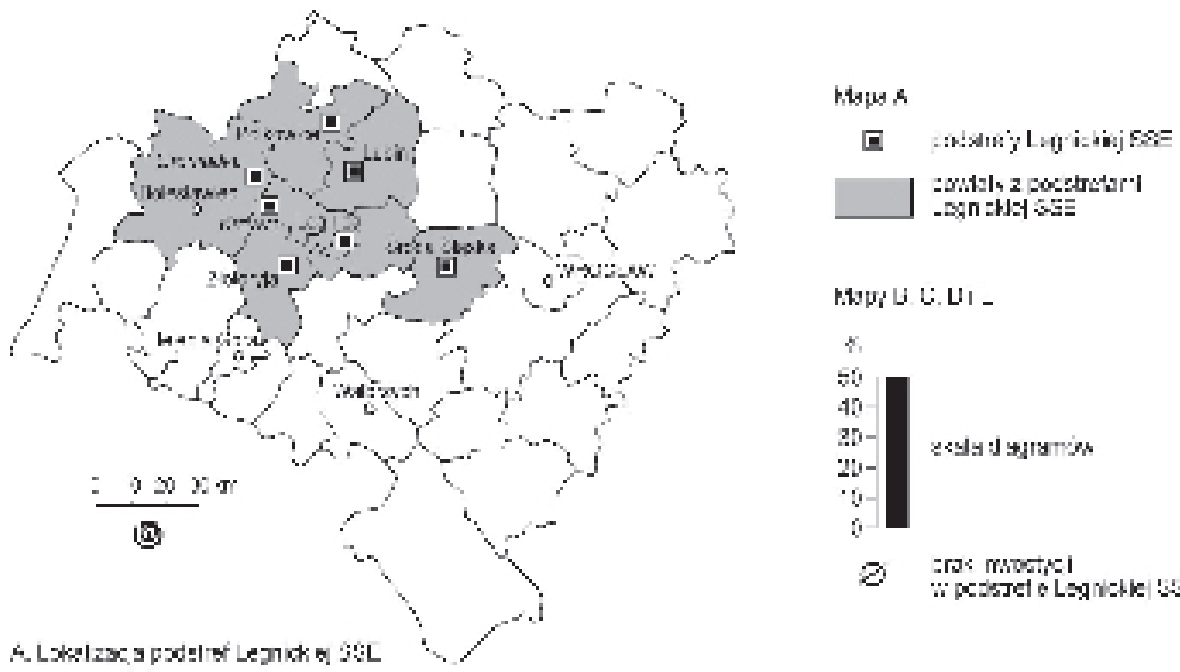

R.wpi U. L.U1 -

s.

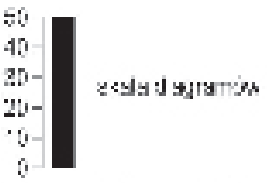

$8 \quad$ ans motel

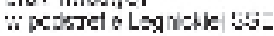

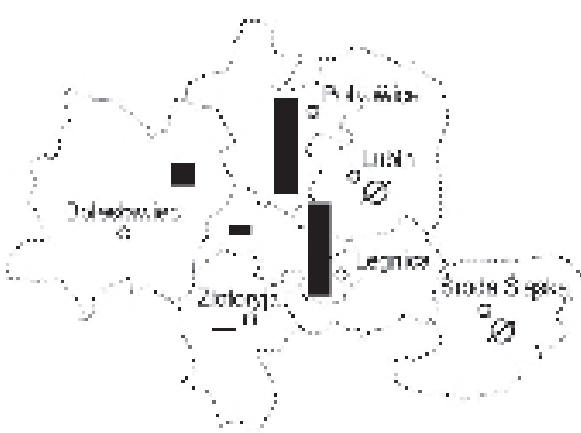

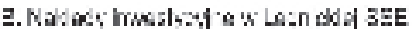

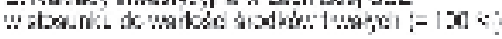

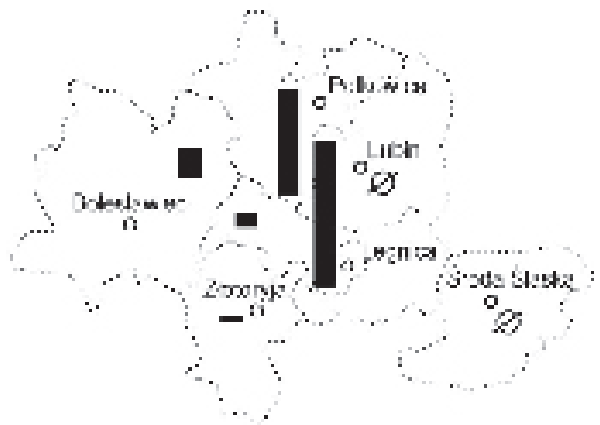

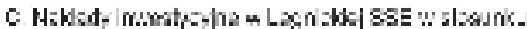

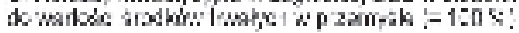

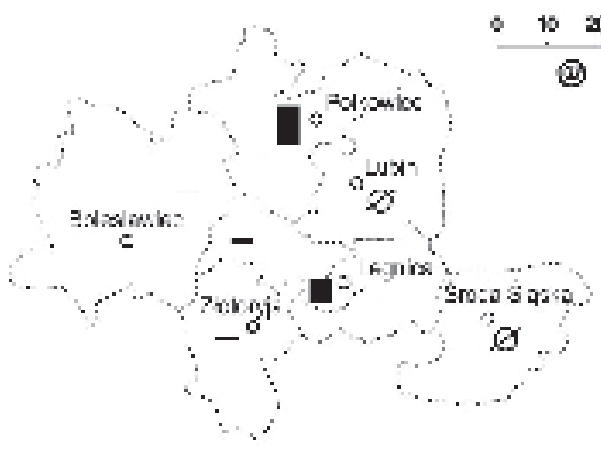

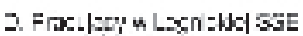

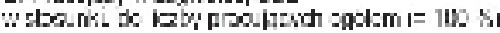

\section{$30 \mathrm{~km}$}

(2)

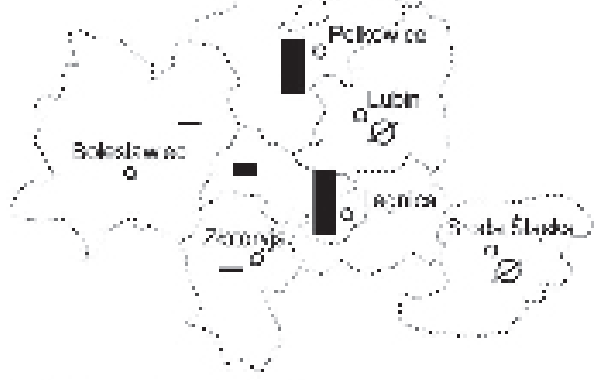

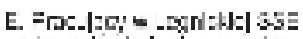

$*$ sx:

Ryc. 8. Nakłady inwestycyjne i pracujący w legnickiej SSE w 2005 r.

Źródło: Opracowanie własne na podstawie http://www.strefa-legnica.com i danych US we Wrocławiu 
Samorządy coraz chętniej zabiegają o utworzenie na swoim terenie specjalnych stref ekonomicznych, ponieważ stają się one szansą na przyciąnnięcie inwestorów, szczególnie zagranicznych, oraz instrumentem skutecznego zmniejszenia bezrobocia i wzrostu potencjału gospodarczego jednostki samorządu terytorialnego. Co prawda preferencyjne warunki działalności dla inwestorów w strefach, w tym zwolnienia od podatku od nieruchomości oraz nakłady samorządów związane z przygotowaniem terenów dla inwestorów, mogą w krótkim okresie spowodować obniżenie wpływów do budżetów gmin i wzrost wydatków, jednak w dłuższej perspektywie nowe inwestycje przynoszą znaczne korzyści dla rozwoju regionu.

W rezultacie nowe podstrefy specjalnych stref ekonomicznych pojawiają się często w miejscach bardzo odległych od tych, w której strefę powołano pierwotnie. W ten sposób ich znaczenie jako instrumentu generującego rozwój gospodarczy i wywołującego określone przekształcenia strukturalne w obszarach problemowych ulega zatarciu. Specjalne strefy ekonomiczne stają się bowiem obecnie dodatkowym atutem w przyciąganiu inwestorów do miejsc o już korzystnych parametrach gospodarczych. Wymownym tego przykładem jest powstanie podstref specjalnych stref ekonomicznych we Wrocławiu i jego bezpośrednim sąsiedztwie.

Należy podkreślić, iż specjalne strefy ekonomiczne przyciągają nie tylko inwestorów zagranicznych, ale są również miejscem funkcjonowania firm krajowych. Z badań struktury pochodzenia kapitału w strefach wynika, że w 2005 r. ponad 21\% nakładów inwestycyjnych było związanych z polskim kapitałem. W wypadku stref dolnośląskich są one miejscem inwestycji głównie kapitału zagranicznego.

Bardziej zasadne wydaje się tworzenie odpowiedniej polityki rozwoju regionów, której jednym z celów powinno być podnoszenie poziomu życia (dochodów) i szans na rynku pracy mieszkańców poszczególnych województw Polski. Wymaga to powiększenia i skierowania wydatków publicznych na przemiany strukturalne (Kryńska 2000). Mogą one nastapić poprzez rozwój infrastruktury technicznej i niematerialne instrumenty służące poprawie jakości środowiska biznesowego w regionach problemowych. Ważną rolę odgrywają także instrumenty wspierania rozwoju regionalnego służące wpływaniu na jakość środowiska biznesowego podejmowane w różnych formach, m.in. udostępniania informacji i usług doradczych, szkolenia i edukacji oraz wspierania badań naukowych i rozwoju technologii. Istnienie bogatej sieci podmiotów, oferujących tego typu usługi, warunkuje obecnie przyciagnnięcie inwestorów, w szczególności zagranicznych, a tym samym bardziej efektywne wykorzystanie potencjału regionu.

Reasumując rozważania na temat dolnośląskich specjalnych stref ekonomicznych można stwierdzić, iż pomimo ich zróżnicowanego stopnia zagospodarowania, należą one do liderów w kraju (głównie wałbrzyska oraz legnicka SSE) pod względem dokonanych nakładów inwestycyjnych i efektywności zagospodarowanej powierzchni. Strefy te coraz bardziej wpływają na gospodarkę Dolnego Śląska, również w układach lokalnych. Stają się także istotnym narzędziem w pozyskiwaniu inwestorów zagranicznych, co wyróżnia ten region w strukturze pochodzenia kapitału w strefach na tle Polski.

Specjalne strefy ekonomiczne w województwie dolnośląskim odgrywają rolę stymulującą w rozwoju gospodarczym regionu i przyczyniają się do zwiększania jego atrakcyjności inwestycyjnej wśród innych województw. Potwierdzeniem tej prawidłowości może być opracowany przez Instytut Badań nad Gospodarką Rynkową ranking atrakcyjności województw, w którym wskazano, iż jednym z głównych atutów województwa dolnośląskiego jest wysoka podaż specjalnych stref ekonomicznych, będących kluczowym składnikiem infrastruktury gospodarczej regionu (Kalinowski 2006). 


\section{Literatura}

Bazydło A., Smętkowski M., 2000, Specjalne strefy ekonomiczne - światowe zróżnicowanie instrumentu, [w:] E. Kryńska (red.), Polskie specjalne strefy ekonomiczne, Warszawa, s. 17-55.

Informacje o specjalnych strefach ekonomicznych w 2005 r., 2006, MGiP, Warszawa.

Kalinowski T., 2006, Atrakcyjność inwestycyjna województw i podregionów Polski 2006, Gdańsk.

Kryńska E., 2000, Specjalne strefy ekonomiczne w Polsce - teraźniejszość i przyszłość, [w:] E. Kryńska (red.), Polskie specjalne strefy ekonomiczne, Warszawa, s. 170-186.

Liberska B., 1999, Czynniki przyciagajace zagraniczne inwestycje bezpośrednie. Wnioski dla Polski $z$ doświadczeń innych krajów, [w:] Z. Sadowski (red.), Kapitał zagraniczny w Polsce. Warunki działania, Warszawa, s. 35-64.

„Prawo i Gospodarka” z 31 sierpnia 2001.

Raport o polityce regionalnej, 2004, MGiP, Warszawa.

Rocznik statystyczny województw z lat 2000, 2001, 2002, 2003, 2004, 2005, GUS, Warszawa.

Rocznik statystyczny województwa jeleniogórskiego, 1998, US w Jeleniej Górze.

Rocznik statystyczny województwa kaliskiego, 1998, US w Kaliszu.

Rocznik statystyczny województwa leszczyńskiego, 1998, US w Lesznie.

Rocznik statystyczny województwa legnickiego, 1998, US w Legnicy.

Rocznik statystyczny województwa wałbrzyskiego, 1998, US w Wałbrzychu.

Rocznik statystyczny województwa wrocławskiego, 1998, US we Wrocławiu.

Rozporzadzenie Rady Ministrów w sprawie ustanowienia specjalnej strefy ekonomicznej w Kamiennej

Górze, Dz. U. z 1997, nr 135, poz. 903.

Rozporzqdzenie Rady Ministrów w sprawie ustanowienia legnickiej specjalnej strefy ekonomicznej,

Dz. U. z 1997, nr 44, poz. 274, oraz Dz. U. z 2000, nr 66, poz. 788.

Rozporzadzenie Rady Ministrów w sprawie ustanowienia wałbrzyskiej specjalnej strefy ekonomicznej,

Dz. U. z 1997, nr 46, poz. 290, oraz Dz. U. z 1999, nr 53, poz. 556.

„Wiadomości Gospodarcze”, 2006, Nr 9, Specjalne strefy ekonomiczne. Stan i perspektywy, PKO Bank

Polski, Departament Strategii, Warszawa, s. 40-47.

Województwo dolnoślaskie w 1998 r., 1999, US we Wrocławiu.

Województwo dolnoślaskie. Podregiony, powiaty i gminy, 2005, US we Wrocławiu.

http://www.strefa-legnica.com

http://www.paiz.gov.pl

\section{Special economic zones in economic space of the Dolnośląskie Voivodship}

A special economic zone (SEZ) is an area of the Republic of Poland separated pursuant to the Law where business activity may be run with more advantageous conditions than the rules of economic activity in the State. Main reasons of establishing of the SEZ are: business activation of regions; restoration of old industrial areas; use of the existing industrial assets and economic infrastructure; establishment of new workplaces, especially in territories with high unemployment; development of new technical and technological solutions and their application in the national economy; increase of competitiveness of the products and services offered.

Now in Poland there are 14 special economic zones. This paper focuses on the influence of the SEZ on region economy, with the Dolnośląskie Voivodship as an example. Three special economic zones in the region stimulate its economic development and bring about an increase of its investment attractiveness among other regions in Poland. The Wałbrzyska SEZ and the Legnicka SEZ belong to the best special economic zones in the country in relation to achieved investment value and effectiveness of the development area.

The investment in a zone the is important for the local economy. The paper describes this question with the Legnicka SEZ as an example. 